\title{
INFLUENZA VIRUS AND PROTEOLYTIC BACTERIA CO-INFECTION IN RESPIRATORY TRACT FROM INDIVIDUALS PRESENTING RESPIRATORY MANIFESTATIONS
}

\author{
Dalva Assunção Portari MANCINI(1), Rosely C. Barbosa ALVES(1), Rita Maria Zucatelli MENDONÇA(1), Nancy J. BELLEI(2), Emerson CARRARO(2),
}

Antonia M.O. MACHADO(3), José Ricardo PINTO(1) \& Jorge MANCINI FILHO(4)

\begin{abstract}
SUMMARY
A role for proteolytic bacteria in the exacerbation of influenza virus has been shown in natural hosts such as pigs and humans. Four hundred seven samples were collected from the respiratory tract of individuals presenting clinical manifestations, during influenza season (2003-2005) in São Paulo City. The aim of this study was to evaluate the incidence of determined bacteria coinfecting virus in human respiratory tract. Tests, such as bacteriological, immunofluorescence (IF), RT/PCR and hemagglutination (HA) were used for bacterial and viral investigation. Thirty seven (9.09\%) positive for influenza virus were screened by IF. The RT/PCR confirmed the presence of influenza virus in these samples. Bacterial and agar casein tests demonstrated that 18 (48.64\%) individuals were infected with proteolytic bacteria such as Staphylococcus spp., Streptococcus spp. and Pseudomonas spp. Among these samples, 13 (35.13\%) were co-infected with influenza A virus. Influenza type B, co-infecting bacteria were found in five (13.51\%) samples. In vitro the $S$. aureus protease increased the influenza HA titer after contact for 30 min at $25{ }^{\circ} \mathrm{C}$. Results revealed the occurrence of co-infection with proteolytic bacteria and influenza in the evaluated individuals. This finding corroborates that virus versus bacteria synergism could be able to potentiate respiratory infection, increasing damage to hosts.
\end{abstract}

KEYWORDS: Influenza; Proteolytic bacteria; Co-infection; Respiratory tract.

\section{INTRODUCTION}

Virus-bacteria association ${ }^{3,17,18}$ infections has been reported to be one of the major causes of severe influenza pneumonia in human, possibly due to the synergistic effect of these microorganisms during the respiratory tract invasion. On the one hand, the influenza virus requires an enzymatic action to achieve the hemagglutinin molecule cleavage that increases its infectivity in host cells; this action is provided by the bacterial protease. On the other hand, the influenza virus can promote bacteria adherence on the host cells, where the bacterial adhesins are able to act when the cells are infected by this virus ${ }^{16}$.

The interaction between bacteria and influenza virus has been studied in vitro as well as in vivo, using different proteases such as urokinase, kallikrein, plasmin and thrombin in comparison with the bacterial protease (staphylokinase and streptokinase) and measuring influenza virus replication. Results indicated that interaction of extracellular proteases with the HA may activate viral infection in both experimental and in natural situations ${ }^{17}$. Even with the uncleaved Hemagglutination (HA), the influenza virus could become infectious through the host cell endoproteases, sometimes induced by enzymatic activation $^{13}$.
In addition to the lack of understanding regarding the association mechanism of bacteria and influenza virus, some studies suggest an enhancement of respiratory infections in this situation ${ }^{3,5,16}$.

Many microorganisms may represent an important source of proteases capable of a proteolytic activation of influenza virus. Staphylococcus aureus, Streptococcus pneumoniae and S. pyogenes are the most common bacteria in respiratory flora, that also includes Pseudomonas aeruginosa and Stenotrophomonas maltophilia; the latter two species of microorganisms coming from environmental sources ${ }^{17}$. In our previous study, an increase of influenza infectivity was observed when these virus isolate samples, collected from natural hosts, were co-infected with $S$. maltophilia ${ }^{10}$.

In the present study, the co-infection influenza virus proteolytic bacteria in samples obtained from individuals presenting respiratory symptoms, including hospitalized patients presenting a situation of immune depression was studied. The ability of these bacterial species to exacerbate influenza in humans, under these conditions, has been investigated. Since there is a lack of these informations in Brazil, our objective was to verify the interaction influenza virus proteolytic bacteria in our country. However, it was not our objective, the evaluation 


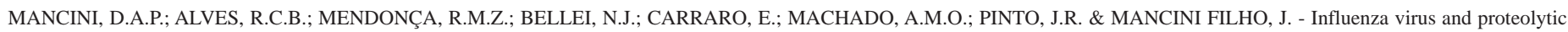
bacteria co-infection in respiratory tract from individuals presenting respiratory manifestations. Rev. Inst. Med. trop. S. Paulo, 50(1): 41-46, 2008.

of the clinical manifestation exacerbations as answers to this coinfection.

\section{MATERIAL AND METHODS}

Microorganism isolation (12): A total of 407 nasal washes were collected with sterile PBS from patients (kidney transplanted), health care workers and general population with respiratory manifestation. Subjects ranged from 12 to 30 years old, were attended at the Universidade Federal de São Paulo (UNIFESP) Hospital, between 2003 and 2005. Samples were provided to both the laboratories of Virology and Bacteriology, and the techniques were performed as follows:

\section{Virological tests}

1.1. Immunofluorescence technique(18): The 407 samples, as referred above, were clarified by centrifugation at 2,000g for $10 \mathrm{~min}$ before screening for influenza positivity by immunofluorescence technique. This was performed initially by addition of mucolytic solution to these samples, followed by centrifugation at 300-500g, and incubation for $10 \mathrm{~min}$ at room temperature, for fixation. After this, monoclonal antibodies to influenza A and B types and parainfluenza viruses, conjugated with fluorescein isothiocyanate, were added on a Light Diagnostic Simulfluor Respiratory Screen (Biotrin ${ }^{\circledR}$ ). After 15 min at $37^{\circ} \mathrm{C}$ (humidity chamber) the smear samples were washed with PBS (Tween) three times, for $10 \mathrm{sec}$ each, and left to dry. Material was then observed by immunofluorescence microscopy (Olympus BX51). Among the prepared samples, a standard influenza sample was included to compare the positive antigen and fluorescent influenza antibody mashes, during the microscopic examination. All samples that presented this feature, revealing fluorescence with a brilliant green color, are considered to be the influenza virus. The other samples, considered not to be influenza antibody reagent, present a red color, due to the Blue Evans stain used for negative test confirmation.

\subsection{Chain Reaction (RT/PCR) technique:}

1.2.1. RNA viral extraction (4): Viral RNA is extracted from screened influenza isolate samples technique utilizing a mixing of 250 $\mu \mathrm{L}$ of the sample and $750 \mu \mathrm{L}$ of the Trizol reagent (Invitrogen ${ }^{\circledR}$ ) and kept at room temperature for five min with addition of the $200 \mu \mathrm{L}$ Chloroform $\left(\right.$ Merck $\left.^{\circledR}\right)$. The samples are mixed by vortexing for $15 \mathrm{sec}$ and kept at room temperature for five min, after this they are centrifuged at $15,294 \mathrm{~g}$ for $15 \mathrm{~min}$ at $4{ }^{\circ} \mathrm{C}$. Four hundred microliters of the supernatant are removed avoiding the interfase and $500 \mu \mathrm{L}$ of the isopropanol $\left(\right.$ Synth $\left.^{\circledR}\right)$, it is then mixed by vortexing for five sec. These samples are centrifuged at $15,294 \mathrm{~g}$ for five min at $4{ }^{\circ} \mathrm{C}$ and discarding the supernatant. To this pellet, 1,000 $\mu \mathrm{L}$ of ethanol (75\%) (Synth ${ }^{\circledR}$ ) are added, and mixed gently following of centrifugation at 15,294 g for 10 min at $4{ }^{\circ} \mathrm{C}$ and discarding the supernatant.

Finally, $20 \mu \mathrm{L}$ of distilled water DNAse, RNAse free are added and incubated at $50{ }^{\circ} \mathrm{C}$ for $10 \mathrm{~min}$. This material is stored at $-70{ }^{\circ} \mathrm{C}$ until performance of the reverse transcription technique.

1.2.2. Reverse transcription/PCR (6): Five microliters of viral RNA are added to $1.0 \mu \mathrm{L}$ of primer PcDNA (flu) and $1.0 \mu \mathrm{L}$ of primer REV, 1.0 $\mu \mathrm{L}$ of $10 \mathrm{mM}$ dNTP mix and $4.0 \mu \mathrm{L}$ of sterile distilled water.
The reaction after heating at $65^{\circ} \mathrm{C}$ for five min is quickly chilled on ice followed by adding $4.0 \mu \mathrm{L}$ of $5 \mathrm{X}$ First Strand Buffer (Invitrogen ${ }^{\circledR}$ ), $2.0 \mu \mathrm{L}$ of $0.1 \mathrm{M}$ DTT $\left(\right.$ Invitrogen $^{\circledR}$ ), $1.0 \mu \mathrm{L}$ of Rnase Out Ribonuclease Inhibitor (Invitrogen ${ }^{\circledR}$ ), and incubated at $37^{\circ} \mathrm{C}$ for two min. Next, it is added $1.0 \mu \mathrm{L}$ (200 units) of RT (M-MLVRT-Invitrogen ${ }^{\circledR}$ ), mixed by pipetting gently, incubated at $37{ }^{\circ} \mathrm{C}$ for $50 \mathrm{~min}$ and the reaction was inactivated by heating at $70{ }^{\circ} \mathrm{C}$ for $15 \mathrm{~min}$. The PCR product, is the viral cDNA that should be stored at $-70{ }^{\circ} \mathrm{C}$.

PCR Reaction for Amplification: Five microliters of cDNA are amplified in a volume of $50.0 \mu \mathrm{L}$ containing $5.0 \mu \mathrm{L}$ PCR buffer $10 \mathrm{X}$ 20 mM Tris-HCl pH 8.4, 500 mM KCl, $1.5 \mu \mathrm{L} 50 \mathrm{mM} \mathrm{MgCl}_{2}, 1.0 \mu \mathrm{L}$ $10 \mathrm{mM}$ dNTP, $35.1 \mu \mathrm{L} \mathrm{H} 2 \mathrm{O}$ DEPEC, $1.0 \mu \mathrm{L}$ of primer PcDNA (- ; FLU), $1.0 \mu \mathrm{L}$ of primer REV(+; Flu) and $0.4 \mu \mathrm{L}(5 \mathrm{U} / \mu \mathrm{L}) \mathrm{Taq}$ polymerase. This reaction mixture is warmed by Thermal Cycler (Bio$\mathrm{Rad}^{\circledR}$ ) at $94{ }^{\circ} \mathrm{C}$ for $45 \mathrm{sec}$ and 35 cycles of: $45 \mathrm{sec}$ at $94^{\circ} \mathrm{C}$; $30 \mathrm{sec}$ at 55 ${ }^{\circ} \mathrm{C} ; 1.3 \mathrm{~min}$ at $72{ }^{\circ} \mathrm{C}$, and $72{ }^{\circ} \mathrm{C}$ for $10 \mathrm{~min}$. Finally, it is left at $4{ }^{\circ} \mathrm{C}$ for indeterminate time. The PCR amplified product is analyzed by $2.0 \%$ agarose gel (Sygma ${ }^{\circledR}$ ) electrophoretic run $60 \mathrm{~V}$ and bands stained with $0.5 \mu \mathrm{g} / \mathrm{mL}$ ethidium bromide, and documented by Fluorescent Table (Vilber-Lourmat ${ }^{\circledR}$ ) and photographed by digital camera $\left(\right.$ Sony $\left.^{\circledR}\right)$. Influenza virus type A (H3N2), used as standard, will confirm the samples positivity through the bands revealed with 189 bp from the primers corresponding to no structural antigen $\{\mathrm{NS} 1\}$ gene fragment of the influenza virus.

Primer PcDNA Sequence (5' to 3'): AAG GGC TTT CAC CGA AGA GG TC

Primer REV Sequence (5' to 3’): CCC ATT CTC ATT ACT GCT

1.3. Hemagglutination (HA) Test (9): Laboratory cell-adapted strain of Influenza virus A/SP/1/91 $\left(\mathrm{H}_{3} \mathrm{~N}_{2}\right)$ after contact, for $60 \mathrm{~min}$ at $25{ }^{\circ} \mathrm{C}$, with bacterial protease samples, performed the virus hemagglutination titer, which is determined at room temperature in a microtiter system. Serial two fold dilutions of virus $(25 \mu \mathrm{L})$ in phosphate-buffered pH 7.2 are mixed with $25 \mu \mathrm{L}$ of a $0.5 \%$ suspension of rooster red blood cells. Hemagglutination titers are determined after one hour, unless otherwise stated, and are expressed as the reciprocal of the maximum dilution of virus that causes complete agglutination.

\subsection{Cytopathic effects in cell culture (7):}

1.4.1. Infection of cell culture by Influenza virus in the presence of bacterial protease: Laboratory cell-adapted strain of Influenza virus type A/SP/1/91 $\left(\mathrm{H}_{3} \mathrm{~N}_{2}\right)$ is used to infect monolayers of MDCK cells. In twelve wells of plastic plaque (Falcon, USA) with cell culture, it was inoculated $0.1 \mathrm{~mL}$ of each influenza virus dilution at $10-1$ to $10-4$ previously contacted with bacterial protease $(0.1 \mathrm{~mL})$ for $60 \mathrm{~min}$ at $25^{\circ} \mathrm{C}$. The plaque with infected cells is left for $30 \mathrm{~min}$ at $33^{\circ} \mathrm{C}$, and then completed with the Leibovitz-15 medium. Controls such as influenza virus replication in absence or presence of trypsin (30 $\mu \mathrm{g} / \mathrm{mL}$ ) and normal cells are performed likewise the experimental test. Four wells are used for each test: experiment and controls. These test results hold on increase of the virus influenza infectivity titer, such as by cytopathic effect (CPE) as well by HAU, both detected after seven days of the virus inoculation, which is the end test. 


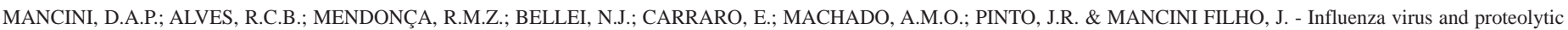
bacteria co-infection in respiratory tract from individuals presenting respiratory manifestations. Rev. Inst. Med. trop. S. Paulo, 50(1): 41-46, 2008.

\section{Bacterial tests (12)}

2.1. Bacterial cultivation and identification: From the total sampling of the 407 collected individuals, thirty seven samples screened by immunofluorescence as influenza positive were chosen for bacteria detection through the cultures in Tryptic Soy Broth (TSB) for 18-24 h at $35{ }^{\circ} \mathrm{C}-37{ }^{\circ} \mathrm{C}$. Samples that presented medium opacity, after this time, were submitted to the identification assay. For this, the cultured bacteria was dropped on glass smears and stained by the Gram technique and then visualized by optic microscopy. The microorganisms, of both coccoids and bacillar morphologies [being Gram $(+)$ or $(-)$ ], were screened by biochemical methods. For Gram positive microorganism identification by catalase test, a serology test was employed using the Staphy Test commercial kit (Probac ${ }^{\circledR}$ ), to identify the Staphylococcus aureus and negative coagulase. This positivity test is observed through the agglutination of the sheep blood sensitized by hemolysin and fibrinogen. Referring to negative test result, that lead to suggest to be Staphylococcus negative coagulase concerning Streptococcus identification, plaques (Petri) with sheep blood agar (5\%) were prepared to differentiate hemolysis types. The material, previously isolated with a coccoid form, as verified by microscopy, was cultured on these plates and Optochine discs added $(5 \mu \mathrm{g})$ (Probac ${ }^{\circledR}$ ) before incubating in $\mathrm{CO}_{2}$ atmosphere (range $5-10 \%$ ) for $24 \mathrm{~h}$ at $37^{\circ} \mathrm{C}$. After this time, the bacterial culture that presented halo $\geq 14 \mathrm{~mm}$ around these discs may be considered as $S$. pneumoniae, and those which demonstrated a green color with halos are identified as $S$. viridans.

Plaques of E.M.B: Agar were used for cultivation of the Gram negative microorganism isolated and identified through biochemical assays. The Pseudomonas spp. can be suspected by betalactams antibiotic resistance.

2.2. Protease Test-Agar Casein Assay (3): Bacterial isolates cultured in Tryptic Soy Broth (TSB) were centrifuged at 12,000g for $15 \mathrm{~min}$ at $4{ }^{\circ} \mathrm{C}$ and filtered through a Millipore $0.45 \mu \mathrm{m}$ pore-diameter syringe filter. Clarified supernatant was tested for proteolytic activity on casein agar plates. Casein agar plates consisted of $25 \mathrm{mM}$ Tris (pH 7.2), $150 \mathrm{mM} \mathrm{NaCl}, 0.6 \%$ casein (Sigma technical grade) and 1\% Bacto Agar $\left(\right.$ Difco $\left.^{\circledR}\right)$. Aliquots $(10 \mu \mathrm{L})$ of culture supernatants are placed in 3 mm diameter wells cut in the casein agar and incubated at $37^{\circ} \mathrm{C}$ for $18 \mathrm{~h}$. The plates are overlaid with $3 \%$ acetic acid, and proteolytic activities are noted as a zone of clearing around the sample well. Trypsin $(1 \mu \mathrm{g} / \mathrm{mL})$ was used as a positive control standard. Caseinolytic activity of the proteolytic bacteria, also relative to trypsin used as a control, was determined by measuring the diameter of the proteolytic zones around each well.

\section{RESULTS}

Through the virological tests, among of the 407 samples collected from individuals presenting respiratory manifestations, thirty seven (9.09\%) samples were chosen that had been previously demonstrated as influenza virus positive by immunofluorescence, in whose samples the parainfluenza was not detected. These samples were identified as being 25 (67.56\%) samples of type A and 12 (32.43\%) of type B. The fluorescent positive influenza sample is shown in Fig. 2. The RT/PCR technique characterized the influenza virus in some samples previously screened for this virus. The electrophoretic bands revealed that the isolated influenza virus strains were compatible with standard influenza A/SP/1/ $91\left(\mathrm{H}_{3} \mathrm{~N}_{2}\right)$. A PcDNA(flu) primer was used to amplify a $189 \mathrm{bp}$ fragment of the non-structural (NS-1) gene of influenza virus in Fig. 3.

Of the eighteen samples (48.64\%) presenting Staphylococcus negative coagulase, Staphylococcus aureus, Streptococcus viridans, Streptococcus pneumoniae and Pseudomonas aeruginosa that were obtained from thirteen (35.13\%) influenza types A and five (13.31\%) B samples and characterized by the bacteriological tests recommended for this type of investigation (Table 1 and Fig. 1). The Agar Casein test showed three samples of these bacteria isolates with protease action, as verified by the zone of clearing around each bacteria sample well. Trypsin represents the proteolytic action control. The Staphylococcus negative coagulase (isolated) and $S$. negative coagulase from ATCC represent the lack of the proteolytic action (Fig. 4).

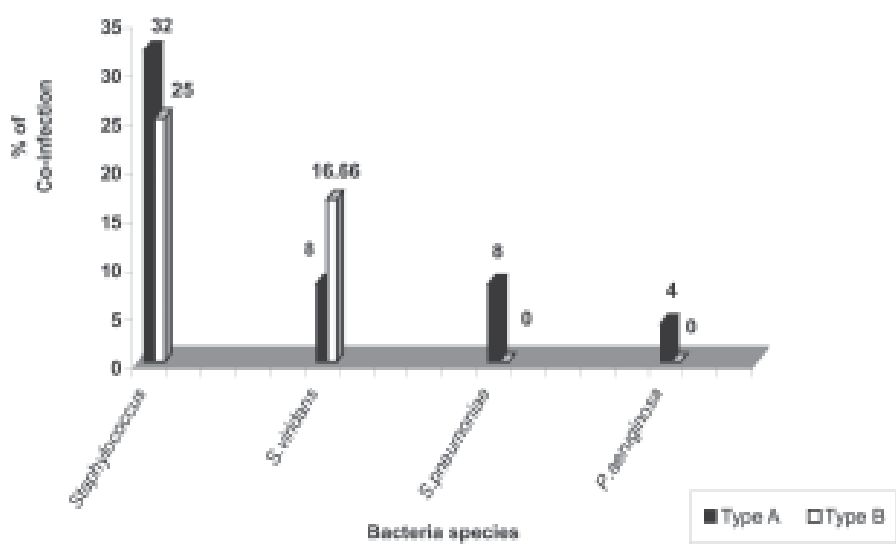

Fig. 1 - Percentage of Staphylococcus spp., Streptococcus viridans, S. pneumoniae and Pseudomonas spp. co-infecting with influenza A and B viruses in nasal washes from patients exhibiting manifestations of respiratory ailment.

Using laboratory cell-adapted strains of influenza virus A/SP/1/91 $\left(\mathrm{H}_{3} \mathrm{~N}_{2}\right)$, contacted or not previously with bacteria proteases from Pseudomonas aeruginosa (sample 68); Staphylococcus aureus (sample 158); Streptococcus viridans (sample 342); Streptococcus pneumoniae (samples 344 and 356), the increase in infection by this virus, as in MDCK cells, was observed by their cytopathic effect (CPE) as well as by their hemagglutinin titers. Trypsin was used to demonstrate enzymatic action on the influenza hemagglutin cleavage, with viral exacerbation. These results are demonstrated in Table 2 and Fig. 5.

Bacteria such as Pseudomonas aeruginosa (sample 68) co-infecting influenza samples, as well as in combination with cell-adapted influenza A $\left(\mathrm{H}_{3} \mathrm{~N}_{2}\right)$ are represented in Fig. 6a and 6b.

\section{DISCUSSION AND CONCLUSION}

Bacteriological and Virological tests demonstrated that the samples collected by nasal wash from individuals presenting respiratory manifestations, revealed bacteria and influenza virus presence concomitantly. The influenza type A was more incident than type B, as well the Staphylococcus reached the higher percentage, in these evaluated samples. 


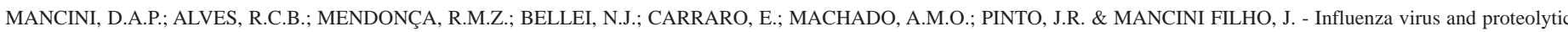
bacteria co-infection in respiratory tract from individuals presenting respiratory manifestations. Rev. Inst. Med. trop. S. Paulo, 50(1): 41-46, 2008.

Table 1

Relation of the detection of influenza virus and bacteria in nasal washes collected from individuals presenting respiratory manifestations

\begin{tabular}{|c|c|c|c|}
\hline \multirow{3}{*}{$\begin{array}{l}\text { Screened } \\
\text { samples }\end{array}$} & \multicolumn{3}{|c|}{ Tests } \\
\hline & \multicolumn{2}{|c|}{$\begin{array}{l}\text { Imunofluorescence } \\
\text { Influenza type }\end{array}$} & \multirow[t]{2}{*}{$\begin{array}{l}\text { Bacteriological identification } \\
\text { Microorganism }\end{array}$} \\
\hline & A & $\mathrm{B}$ & \\
\hline 1 & + & - & $\mathrm{N}$ \\
\hline 2 & + & - & $\begin{array}{l}\text { Staphylococcus negative } \\
\text { coagulase }\end{array}$ \\
\hline 5 & - & + & Streptococcus viridans \\
\hline 7 & - & + & Streptococcus viridans \\
\hline 16 & + & - & $\mathrm{N}$ \\
\hline 24 & + & - & $\mathrm{N}$ \\
\hline 25 & - & + & $\mathrm{N}$ \\
\hline 27 & - & + & $\mathrm{N}$ \\
\hline 28 & + & - & $\mathrm{N}$ \\
\hline 29 & - & + & Staphylococcus aureus \\
\hline 30 & + & - & Staphylococcus aureus \\
\hline 36 & - & + & $\mathrm{N}$ \\
\hline 38 & + & - & $\mathrm{N}$ \\
\hline 39 & - & + & $\mathrm{N}$ \\
\hline 40 & + & - & $\mathrm{N}$ \\
\hline 68 & + & - & Pseudomonas aeruginosa \\
\hline 116 & - & + & $\begin{array}{l}\text { Staphylococcus negative } \\
\text { coagulase }\end{array}$ \\
\hline 130 & - & + & $\mathrm{N}$ \\
\hline 142 & + & - & $\begin{array}{l}\text { Staphylococcus negative } \\
\text { coagulase }\end{array}$ \\
\hline 147 & + & - & $\begin{array}{l}\text { Staphylococcus negative } \\
\text { coagulase }\end{array}$ \\
\hline 149 & - & + & $\mathrm{N}$ \\
\hline 151 & - & + & $\mathrm{N}$ \\
\hline 152 & + & - & Staphylococcus aureus \\
\hline 155 & - & + & $\begin{array}{l}\text { Staphylococcus negative } \\
\text { coagulase }\end{array}$ \\
\hline 156 & + & - & $\mathrm{N}$ \\
\hline 158 & + & - & Staphylococcus aureus \\
\hline 159 & + & - & $\mathrm{N}$ \\
\hline 327 & + & - & Staphylococcus aureus \\
\hline 340 & + & - & $\mathrm{N}$ \\
\hline 342 & + & - & Streptococcus viridans \\
\hline 344 & + & - & Streptococcus pneumoniae \\
\hline 346 & + & - & $\mathrm{N}$ \\
\hline 356 & + & - & Streptococcus pneumoniae \\
\hline 358 & + & - & Staphylococcus aureus \\
\hline 366 & + & - & $\mathrm{N}$ \\
\hline 367 & + & - & Streptococcus viridans \\
\hline 375 & + & - & $\mathrm{N}$ \\
\hline 37 & $25(67.56 \%)$ & $12(32.43 \%)$ & $18(48.64 \%)$ \\
\hline
\end{tabular}

$\mathrm{N}$ - Negative.
Proteolytic bacteria, such as Pseudomonas spp., Staphylococcus spp. and Streptococcus spp., were identified in these samples. The protease action of these bacteria was demonstrated by the assay performed with cell-adapted influenza virus $\mathrm{A}\left(\mathrm{H}_{3} \mathrm{~N}_{2}\right)$ that was exacerbated through contact with the bacteria isolates. Influenza

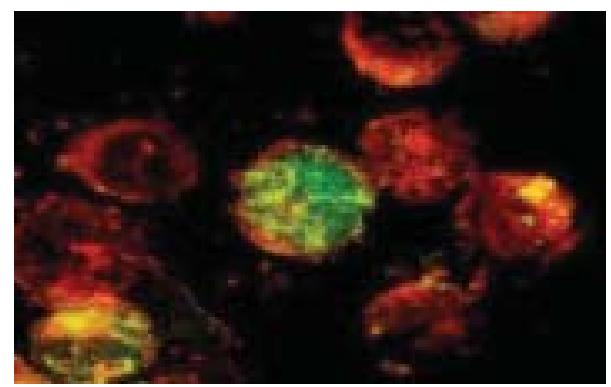

Fig. 2 - Immunofluorescence micrograph of the influenza virus in nasal washes from patients exhibiting symptoms of respiratory ailment. - Green = Positive Antibody reaction to the Influenza virus; - Red = Negative Antibody reaction to the Influenza virus.

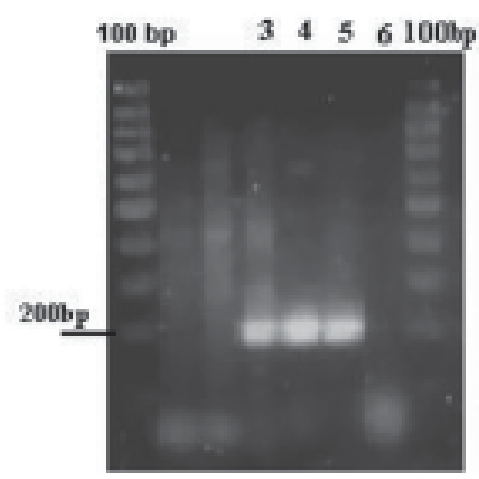

Fig. 3 - Characterization by RT/PCR of the influenza virus in nasal washes from patients presenting respiratory ailments manifestations. Lane 3 - Sample \# 68; Lane 4 - Sample \# 342; Lane 5 - Influenza virus type A(H3N2); Lane 6 - Distilled water.

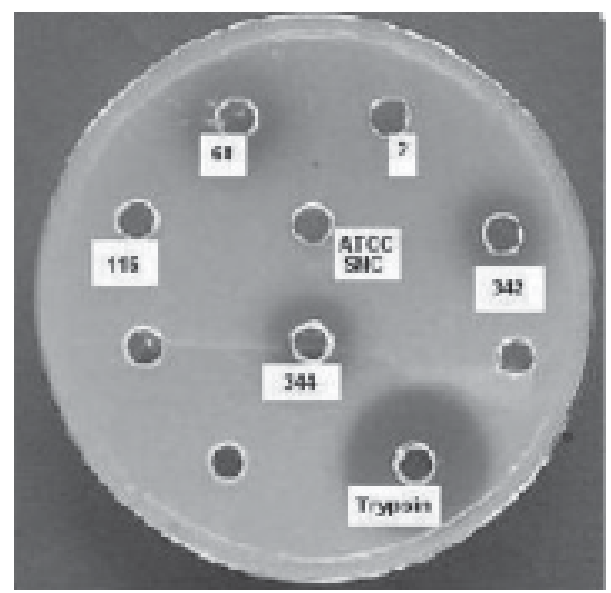

Fig. 4 - Agar-Casein Test - Protease-positive Bacteria co-infecting samples of influenza virus isolate. \#68 - Pseudomonas aeruginosa - Protease Positive; \#342 - Streptococcus viridans Protease Positive; \#344 - Streptococcus pneumoniae - Protease Positive; \#2 - Staphylococcus negative coagulase; \#116 - Staphylococcus negative coagulase; ATCC/SNC - Protease Negative Control; Trypsin - Protease Positive Control. 


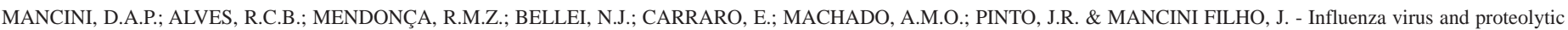
bacteria co-infection in respiratory tract from individuals presenting respiratory manifestations. Rev. Inst. Med. trop. S. Paulo, 50(1): 41-46, 2008.

Table 2

Cell-adapted influenza type $\mathrm{A}\left(\mathrm{H}_{3} \mathrm{~N}_{2}\right)$ strain infectivity $\left(\mathrm{TCID}_{50 \%}\right)$ and hemagglutining titer exacerbations by co-infection with proteolytic bacteria

\begin{tabular}{|c|c|c|c|c|c|}
\hline \multirow{2}{*}{$\begin{array}{l}\text { Dilution } \\
\text { Influenza } \\
+ \text { Bacteria } \\
\text { Protease }\end{array}$} & \multicolumn{4}{|c|}{$\begin{array}{c}\text { Influenza Infectivity by CPE } \\
\text { Sample }\end{array}$} & \multirow{2}{*}{$\begin{array}{c}\text { Virus } \\
\text { Control } \\
\text { Trypsin }\end{array}$} \\
\hline & \#68 & \#342 & \#344 & \#356 & \\
\hline $10^{-1}$ & $70 \%$ & $100 \%$ & $100 \%$ & $100 \%$ & $75 \%$ \\
\hline $10^{-2}$ & $65 \%$ & $70 \%$ & $70 \%$ & $70 \%$ & $60 \%$ \\
\hline $10^{-3}$ & $60 \%$ & $60 \%$ & $65 \%$ & $65 \%$ & $40 \%$ \\
\hline $10^{-4}$ & $40 \%$ & $50 \%$ & $50 \%$ & $60 \%$ & $30 \%$ \\
\hline $10^{-5}$ & $30 \%$ & $40 \%$ & $40 \%$ & $40 \%$ & $10 \%$ \\
\hline $\mathrm{TCID}_{50}$ & $10^{3.4}$ & $10^{3.7}$ & $10^{4.0}$ & $10^{4.0}$ & $10^{2.8}$ \\
\hline TITER (HAU) & 25 & 28.8 & 36 & 38 & 8 \\
\hline
\end{tabular}

CPE - Cytopathic Effect; TCID $_{50}$ - Tissue Cell Infectious Doses; HA Hemagglutination; HAU - Hemagglutinating Unit.

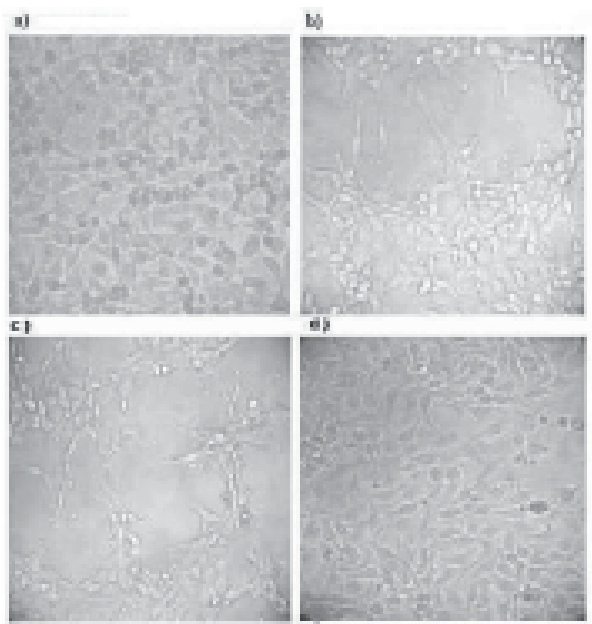

Fig. 5 - Cytopathic effect of the cell-adapted influenza A virus (H3N2) with and without protease in MDCK cells. a) - Normal MDCK cells; b) - Influenza X Bacterial Protease; c) Influenza X Trypsin; d) Influenza without Protease. a)

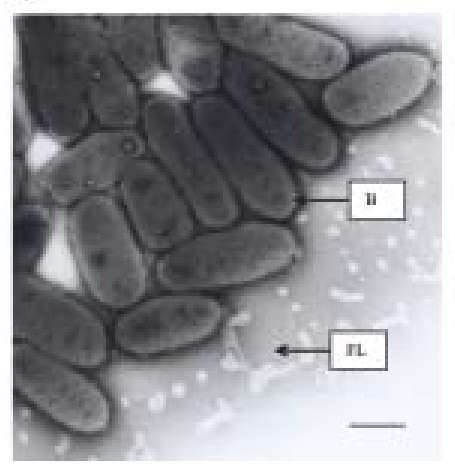

b)

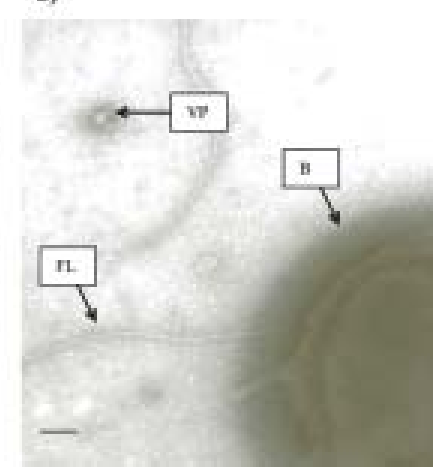

Fig. 6 - Electron micrograph of proteolytic bacteria present in influenza samples isolated from hospitalized patients. a) Sample \#68 - Pseudomonas aeruginosa; $\mathrm{B}=$ Bacteria; FL = Flagellum; Magnification = 15,455 X; Scale bar = $100 \mathrm{~nm}$. b) Cell-adapted influenza virus A (H3N2) in contact with bacteria; $\mathrm{B}=$ Bacterium; VP = Viral Particle; FL = Flagellum; Magnification $=35,089$ X; Scale bar $=100 \mathrm{~nm}$. infectious and hemagglutinin titers were amplified by co-infecting with proteolytic bacteria, compared with trypsin presence or absent in these tests. Then, considering this finding with regards to exacerbation of the influenza virus infectivity by bacterial protease, observed in vitro, lead to suggest the damage that this co-infection causes to the hosts.

Thus, observations since the early eighties by authors such as TASHIRO et al., 1987, BULGAKOVA et al., 1987, demonstrate these bacteria as being responsible for fatal disease in mice lungs, when coinfected with influenza virus. These studies were continued over twenty decades ${ }^{11}$, demonstrating the lethal synergism between influenza virus and Streptococcus pneumoniae that led to $100 \%$ of mortality in mice used as an experimental model. This finding has been related not only in animal models; a synergism between bacteria-influenza virus has been reported, and also observed in children with pneumococcal pneumonia that preceded influenza infection ${ }^{14}$ at the Centers of Disease Control, in Atlanta, USA. Once again, hospitalized children with Community Acquired Pneumoniae (CAP), provoked by influenza infection concomitant with Streptococcus pneumoniae, were evaluated by PONS-CATALANO et al., 2003. Recently, BEADLING \& SLIFKA, 2004, reported that bacterial sepsis was a leading cause of death in the United States, where the mechanisms of lethal synergism between bacteria and influenza virus are responsible for the sepsis in these hospitalized individuals. Authors suggest that preventive measures, including vaccination against influenza and aggressive anti-microbial therapy, early on the course of infection, may reduce the morbidity and mortality by sepsis.

Based on our data and the other reports cited, it may be concluded that co-infection between these microorganisms exacerbates respiratory infections. This situation may be aggravated in hospitalized individuals with immune depression, such as in some patients evaluated in this work. The clinical exacerbations had been not investigated in this work. Even so, this could occur among the evaluated subjects. Therefore, beyond the cited measurements suggested for this preventive control, it is important to currently investigate the most frequent bacterial species that could be associated with influenza virus infection, in the hospital environment, to offer the appropriate medical action against these infectious agents.

About this issue, natural antioxidants from spice extracts are being used as anti-microbials in these bacterial isolates, following our previous findings on the anti-viral action of phenolic compounds, present in natural antioxidants, including the rosemary spice ${ }^{8}$. In addition, inhibitors against bacterial proteinase are being recommended to ameliorate the anti-pathological processes, with reduction of growth rate of the invading organism, allowing the host defense response to be re-established ${ }^{20}$. These findings require further studies, to investigate the synergism between cell endoproteases and microbial proteases in the cleavage of influenza hemagglutinins, as well the cell-adhesin bacteria, favored by the influenza virus, which certainly could potentiate the clinical manifestations of respiratory infections.

The first step of this study had been lead to investigate the incidence of co-infection between virus and proteolytic bacteria, with stand out the influenza infection exacerbation, and the next step will be expended with regards to the bacterial infection exacerbation, under viral coinfection conditions. 


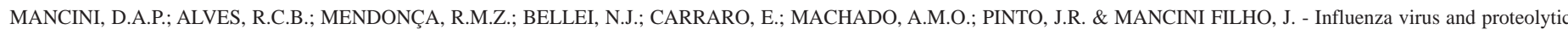
bacteria co-infection in respiratory tract from individuals presenting respiratory manifestations. Rev. Inst. Med. trop. S. Paulo, 50(1): 41-46, 2008.

\section{RESUMO}

\section{Vírus influenza e bactéria proteolítica co-infectantes em trato respiratório de indivíduos com manifestações respiratórias}

O papel da bactéria proteolítica na exacerbação do vírus influenza tem sido demonstrado em hospedeiros naturais como porcos e humanos. Foram coletadas 407 amostras do trato respiratório de indivíduos apresentando manifestações clínicas, durante a estação da influenza (2003-2005) na cidade de São Paulo. Este trabalho teve como objetivo avaliar a incidência de determinadas bactérias que junto com vírus coinfectarem o trato respiratório humano. Testes bacteriológicos, e virológicos como imunofluorescência (IF), RT/PCR e hemaglutinação (HA) foram usados nas investigações viral e bacteriana. Pelo teste de IF foram selecionadas trinta e sete $(9,09 \%)$ amostras positivas para o vírus influenza. A presença do vírus influenza foi confirmada pela técnica de RT/PCR. Pelos testes bacteriológicos e do agar caseina, verificou-se que 18 (48,64\%) dos indivíduos foram infectados com bactérias proteolíticas tais como Staphylococcus spp., Streptococcus spp. e Pseudomonas spp. Destas amostras, 13 (35,13\%) foram coinfectadas com vírus influenza tipo A, e 5 (13,51\%) com influenza tipo B. No experimento in vitro com influenza e $S$. aureus, detectou-se aumento do título hemaglutinante deste vírus, após contacto de 30 min a $25{ }^{\circ} \mathrm{C}$. Os resultados obtidos revelaram a ocorrência de coinfecção com bactéria proteolítica e vírus influenza nos indivíduos avaliados. Estes achados corroboram com a investigação do sinergismo, entre bactéria e vírus, que poderia ser capaz de potencializar infecção respiratória, aumentando os riscos aos hospedeiros.

\section{ACKNOWLEDGMENT}

The authors are grateful to Financial Support from CNPq Proc. 470937/03-3 and also to both Mrs. Luzia da Purificação for her laboratory services, and Laboratório de Biologia Celular, at Instituto Butantan, for electron microscopy studies.

\section{REFERENCES}

1. BEADLING, C. \& SLIFKA M.K.- How do viral infections predispose patients to bacterial infections? Curr. Opin. infect. Dis., 17: 185-191, 2004.

2. BULGAKOVA, T.N.; GRABOVSKAIA, K.B. \& ZUEVA, O.P. - Effect of the influenza A virus on the sensitivity of mice to infection caused by Streptococcus group B. Zh. Mikrobiol. Epidemiol. Immunobiol., 8: 23-29, 1987.

3. CALLAN, R.J.; HARTMANN, F.A.; WEST, S.E.H. \& HINSHAW, V.S. - Cleavage of influenza A virus $\mathrm{H} 1$ hemagglutinin by swine respiratory bacterial proteases. J. Virol., 71: 7579-7585, 1997.

4. CLAAS, E.C.J.; SPRENGER, M.J.W.; KLETER, G.E.M. et al. - Type-specific identification of influenza viruses A, B and C by PCR. J. virol. Meth., 39: 1-13, 1992.

5. HAMENT, J.M.; KIMPER, J.L.; FLEER, A. \& WOLFS, T.F. - Respiratory viral infection predisposing for bacterial disease: a concise review. FEMS Immunol. med. Microbiol., 26: 189-195, 1999.
6. KAWAMOTO, A.H.N.; MANCINI, D.A.P.; PEREIRA L.E. et al. - Investigation of influenza in migrating birds, the primordial reservoir and transmitters of influenza in Brazil. Braz. J. Microbiol., 36: 84-89, 2005.

7. MANCINI, D.A.P. \& YANO A.B. - Avaliação da tripsina na multiplicação de vírus influenza em cultura de células MDCK. Rev. Farm. Bioquím. Univ. S. Paulo, 29: 89-95, 1993.

8. MANCINI, D.A.P.; DIAS, A.L.F.; PINTO, J.R. \& MANCINI-FILHO, J. - Antioxidantes do extrato aquoso da canela (Cinnamomum Zeylanicum, Blume) como inibidores do vírus influenza. Braz. J. pharm. Sci., 35: 155-159, 1999.

9. MANCINI, D.A.P.; MENDONÇA, R.M.Z.; CIANCIARULLO, A.M. \& PINTO, J.R. Influenza nos animais heterotérmicos. Rev. Soc. bras. Med. trop., 37: 204-209, 2004.

10. MANCINI, D.A.P.; MENDONÇA, R.M.Z.; DIAS A.L.F.; MENDONÇA, R.Z. \& PINTO, J.R. - Co- infection between influenza virus and flagellated bacteria. Rev. Inst. Med. trop. S. Paulo, 47: 275-280, 2005.

11. McCULLERS, J.A. \& REHG, J.E. - Lethal synergism between influenza virus and Streptopcoccus pneumoniae: characterization of a mouse model and the role of platelet-activating factor receptor. J. infect. Dis., 186: 341-350, 2002.

12. MURRAY, P.R.; BARON, E.J.; PFALLER, M.A.; TENOVER, F.C. \& YOLKEN, R.H. Manual of clinical Microbiology. 6. ed. Washington, American Society of Microbiology, 1997.

13. NAGATAKE, T. - Potentiation of infectivity and pathogenesis of influenza virus by host and bacterial proteases. Nippon Rinsho, 61: 1892-1896, 2003.

14. O’BRIEN, K.L.; WALTERS, M.I.; SELLMAN, J. et al. - Severe pneumococcal pneumonia in previously health children: the role of preceding influenza infection. Clin. infect. Dis., 30: 784-789, 2000.

15. PONS-CATALANO, C.; VALLET, C.; LORROT. M. et al. - Community acquired pneumonia and influenza in children. Arch. Pediat., 10: 1056-1060, 2003.

16. SANFORD, B.A. \& RAMSAY, M.A. - In vivo localization of Staphylococcus aureus in nasal tissues of healthy and influenza A virus-infected ferrets. Proc. Soc. exp. Biol. (N.Y.), 191: 163-169, 1989.

17. SCHEIBLAUER, H.; REINACHER, M.; TASHIRO, M. \& ROTT, R. - Interactions between bacteria and influenza A virus in the development of influenza pneumonia. J. infect. Dis., 166: 783-791, 1992.

18. STUART-HARRIS, C.H.; SCHILD, G.C. \& OXFORD, J.S. - Influenza - the human disease. In: Influenza. The viruses and the disease. 2. ed. London, Arnold, 1985. p. 103-117.

19. TASHIRO, M.; CIBOROWSKI, P.; REINACHER, M. et al. - Synergistic role of staphylococcal proteases in the induction of influenza virus pathogenicity. Virology, 157: 421-430, 1987.

20. TRAVIS, J.; POTEMPA, J. \& MAEDA, H. - Are bacterial proteinases pathogenic factors? Trends Microbiol., 3: 405-407, 1995.

Received: 31 January 2007

Accepted: 8 August 2007 